PART III. OTHER

DZIAŁ III. RÓŻNE

\title{
EFFECTIVENESS OF HEMOPERFUSION IN TREATMENT OF PATIENTS WITH NON-BILIARY MODERATELY SEVERE PANCREATITIS
}

\section{SKUTECZNOŚĆ ZASTOSOWANIA HEMOPERFUZJI W LECZENIU PACJENTÓW Z OSTRYM MARTWICZYM ZAPALENIEM TRZUSTKI}

\author{
Oleksandr Oliynyk ${ }^{1(A, B, C, D, E, F)}$, Anna Ślifirczyk ${ }^{2(A, C, D, E, F)}$, \\ Bogdana Pereviznyk $^{3(E, F)}$, Wiktor Kushnarov ${ }^{4(B, C, F)}$
}

\author{
${ }^{1} 1$ Bogomolets National Medical University in Kyiv, Ukraine \\ ${ }^{2}$ Pope John Paul II State School of Higher Education in Biala Podlaska, Poland \\ ${ }^{3}$ Horbachevsky Ternopil State Medical University, Ukraine \\ ${ }^{4}$ Ternopil University Hospital, Ukraine
}

Authors' contribution Wkład autorów:

A. Study design/planning zaplanowanie badań B. Data collection/entry zebranie danych C. Data analysis/statistics dane - analiza i statystyki D. Data interpretation interpretacja danych E. Preparation of manuscript przygotowanie artykułu F. Literature analysis/search wyszukiwanie i analiza literatury G. Funds collection zebranie funduszy

\section{Summary}

Background. Acute pancreatitis morbidity has been rising annually all around the world. In case of acute necrotic pancreatitis, the mortality reaches $40 \%$ in the majority of hospitals. The therapy is effective if the efferent methods involve complex therapy of this disease. One such method is hemoperfusion, i.e. extracorporeal blood purification, which is widely used in toxicology. The authors of the article used hemoperfusion in a complex therapy in patients with severe acute pancreatitis. The following research presents an evaluation of the results of hemoperfusion used in a complex therapy of patients with acute pancreatitis. Material and methods. The study involved 38 patients with acute non-biliary moderately severe pancreatitis who were treated at an intensive care unit of Ternopil University Hospital in Ukraine. 18 patients were treated following the protocol for treatment of acute pancreatitis. In 20 patients, this treatment was additionally combined with hemoperfusion. We determined the levels of amylase, diastase, procalcitonin, bilirubin, malonic dialdehyde, and diene conjugates in blood serum and the level of leukocytes in the blood. Results. The levels of procalcitonin, amylase, bilirubin, leukocytes number, malonic dialdehyde, and diene conjugates were stabilised in patients of both groups, but in those who received hemoperfusion demonstrated much better results. These were manifested by significantly better levels of the amylase, bilirubin, creatinine, urea, procalcitonin, malonic dialdehyde, and diene conjugates in patients who received hemoperfusion $(p<0.005)$ than in the other group undergoing standard drug therapy. Conclusions. Hemoperfusion can be used as an effective method in the complex treatment of patients with acute pancreatitis.

Keywords: acute pancreatitis, hemoperfusion, amylase, procalcitonin

\section{Streszczenie}

Wprowadzenie. Corocznie na całym świecie obserwuje się wzrost zachorowalności na ostre zapalenie trzustki. W przypadku ostrego martwiczego zapalenia trzustki śmiertelność w większości szpitali osiąga 40\%. Terapia jest skuteczna, jeśli metody odprowadzające obejmują kompleksową terapię tej choroby. Jedną z takich metod jest hemoperfuzja, tj. pozaustrojowa hemodializa krwi, szeroko stosowane w toksykologii. Autorzy artykułu zastosowali hemoperfuzję $\mathrm{w}$ kompleksowej terapii u pacjentów z ciężkim ostrym zapaleniem trzustki. Poniższe badania przedstawiaja ocenę wyników hemoperfuzji stosowanej w kompleksowej terapii pacjentów z ostrym zapaleniem trzustki. Materiał i metody. W badaniu wzięło udział 38 pacjentów z ostrym, niezłośliwym i umiarkowanie ciężkim zapaleniem trzustki; leczonych w oddziale intensywnej opieki medycznej szpitala uniwersyteckiego na Ukrainie. Zgodnie z protokołem leczenia ostrego zapalenia trzustki leczono18 pacjentów. U 20 pacjentów leczenie to połączono dodatkowo z hemoperfuzją. Określono poziom amylazy, diastazy, prokalcytoniny, bilirubiny, dialdehydu malonowego i koniugatów dienowych w surowicy krwi oraz poziom leukocytów we krwi. Wyniki. Poziom prokalcytoniny, amylazy, bilirubiny, liczby leukocytów, dialdehydu malonowego i koniugatów dienowych były stabilizowane u pacjentów z obu grup, ale u tych pacjentów, u których włączono hemoperfuzję, wyniki były zdecydowanie lepsze. Przejawiały się one znacznie wyższym poziomem amylazy, bilirubiny, kreatyniny, mocznika, prokalcytoniny, dialdehydu malonowego i dienowych koniugatów u pacjentów, którym włączono hemoperfuzję hemoperfuzję $(\mathrm{p}<0,005)$ niż w drugiej grupie poddawanej standardowej terapii lekowej. Wnioski. Hemoperfuzja może być stosowana jako skuteczna metoda w kompleksowym leczeniu pacjentów z ostrym zapaleniem trzustki.
Słowa kluczowe: ostre zapalenie trzustki, hemoperfuzja, amylaza, prokalcytonina
Tables: 1

References: 11

Submitted: 2017 Aug 18

Accepted: 2018 Jan 23

Oliynyk 0, Ślifirczyk A, Pereviznyk B, Kusharov V. Effectiveness of hemoperfusion in treatment of patients with non-biliary moderately severe pancreatitis. Health Prob Civil. 2018; 12(3): 204-208. https://doi.org/10.5114/hpc.2018.76521

Address for correspondence / Adres korespondencyjny: Anna Ślifirczyk, Pope John Paul II State School of Higher Education in Biała Podlaska, Sidorska 95/97, 21-500 Biała Podlaska, Poland, e-mail: aslifirczyk1@gmail.com, phone: 508238088

Copyright: (C) Pope John Paul II State School of Higher Education in Biała Podlaska, Oleksandr Oliynyk, Anna Ślifirczyk, Bogdana Pereviznyk, Wiktor Kushnarov. This is an Open Access journal, all articles are distributed under the terms of the Creative Commons Attribution-NonCommercial-ShareAlike 4.0 International (CC BY-NCSA 4.0) License (http://creativecommons.org/licenses/by-nc-sa/4.0/), allowing third parties to copy and redistribute the material in any medium or format and to remix, transform, and build upon the material, provided the original work is properly cited and states its license. 


\section{Introduction}

The number of patients with acute pancreatitis (AP) rises, and those with destructive forms amounts to 20-30\% [1]. Even in big specialised hospitals, general and post-operative mortality does not fall, especially in case of infected forms of pancreonecrosis, which fall within 15 and 40\%, or more [2]. According to the data, the research aimed at studying different methods of treatment of pancreonecrosis may have a significant practical value. The course of pancreonecrosis is frequently complicated with the development of severe sepsis. It is known that the usage of extracorporeal blood purification in the treatment of severe sepsis and septic shock, particularly hemofiltration and hemoperfusion is very successful $[3,4,5,6]$. The research has demonstrated the effectiveness of this treatment, especially in patients with abdominal and gram-negative sepsis.

It was also found that there is some study on the successful usage of combination hemodialysis and hemoperfusion in treatment of AP, which was the complication of crush syndrome [7]. However, no fundamental research on its usage in the treatment of AP was found. The method of hemoperfusion is successfully used in a complex therapy of AP at the University Hospital of Ternopil State Medical University.

This research forwards the description of this treatment method. To our mind, this data are very essential as they prove that the hemoperfusion method can be used in the treatment of AP. It is vital and should be considered as the current methods of treatment do not ensure much effectiveness.

\section{Material and methods}

The study involved 38 patients with acute non-biliary moderately severe pancreatitis who were treated at the intensive care unit of Ternopil University Hospital in the years 2015-2016. The patients were in the early (within 1 week) phase of AP, characterised by transient organ failure, lasting less than $48 \mathrm{~h}$. Alcohol pancreatitis was diagnosed in 7 patients, alimentary - in 16 patients, posttraumatic - in 15 patients. The diagnosis of AP was established by the presence of 2 of the 3 following criteria: abdominal pain, consistent with the disease, serum amylase greater than three times the upper limit of normal, and/or characteristic findings in abdominal imaging. Transabdominal ultrasound was performed in all patients. Contrast-enhanced computed tomography (CECT) of the pancreas was used in patients in whom the diagnosis was unclear or who failed to improve clinically within the first 48 - 72 hrs. after hospital admission or to evaluate complications. Traditional treatment was administered in all patients with AP. Aggressive hydration, defined as 250-500 ml per hour of isotonic crystalloid solution, was provided to all patients in the first 12 - $24 \mathrm{hrs}$. Lactated Ringer's solution was the preferred isotonic crystalloid replacement fluid. Antibiotics were given only for an extrapancreatic infection such as cholangitis, catheter-acquired infections, bacteremia, urinary tract infections or pneumonia. Enteral nutrition was initiated to prevent infectious complications. Parenteral nutrition was avoided unless the enteral route was not available or not tolerated. Nasojejunal delivery of enteral feeding was applied. All patients received synthetic octapeptide derivative of the natural hormone somatostatin - sandostatin, which has similar pharmacological effects, but much longer duration of action. The drug inhibits pathologically increased secretion of serotonin. The dose of sandostatin was $0,3 \mathrm{mg}$ daily (8).

Patients were divided into 2 groups. The first group (18 patients) were treated following the protocol for the treatment of acute pancreatitis. In the other group (20 patients), this treatment was additionally combined with hemoperfusion. Hemoperfusion was implemented as a supplement to the general guideline principles on 1-3 day after the patients' hospitalisation in the intensive care unit. Hemoperfusion was done just after the rehydration of patients. This procedure was implemented by apparatus "Hemofenix" and sorbent SCN. The patients obtained from 1 to 5 seances of hemoperfusion with a break of 1-3 days between the seances. The following paper describes the results obtained after the $2^{\text {nd }}$ séance of hemoperfusion (if patient obtained only 1 séance - the results were also described).

Since the distribution law for derived indices differed from the normal one, a non-parametric test was used. In this particular case, the test for dependent quantities should be used. Therefore, the Wilkinson test - a matchedpairs test, was applied. The marked asymmetry in the frequency distribution of indices having been obtained, the description of the median and quartile was found appropriate. The value of these indices is determined by their position in the system of the ranked value of indices and, regardless of the distribution law, serves as structural averages or variation indices. These indices are used for establishing one or another standard. The software "Statistica 10" was applied to do the computation.

The permission for research implementation was given by Bioethics commission of Ternopil State Medical University (protocol №29 from 20.05.2015). 


\section{Results and discussion}

The described treatment caused better outcomes of the studied parameters in both patient groups. In contrast to standard treatment, there was a noticeable improvement when hemoperfusion was involved, and the results were significantly better. The results are presented in Table 1.

Table 1. Treatment of patients with non-biliary moderately-severe pancreatitis

\begin{tabular}{|c|c|c|c|c|c|}
\hline \multirow[b]{2}{*}{ Parameters } & \multicolumn{5}{|c|}{ Data } \\
\hline & Median & Minimum & Maximum & $\begin{array}{c}\text { Lower } \\
\text { quartile }\end{array}$ & $\begin{array}{c}\text { Upper } \\
\text { quartile }\end{array}$ \\
\hline $\begin{array}{l}\text { Body temperature in Celsius, } \\
\text { before treatment }\end{array}$ & 37.30 & 36.50 & 39.000 & 37.30 & 37.60 \\
\hline $\begin{array}{l}\text { Body temperature in Celsius, } \\
\text { standard treatment }\end{array}$ & 37.30 & 36.80 & 37.800 & 37.00 & 37.50 \\
\hline $\begin{array}{l}\text { Body temperature in Celsius, } \\
\text { additional hemoperfusion }\end{array}$ & $36.60^{*}$ & 36.00 & 38.000 & 36.20 & 36.60 \\
\hline Saturation, before treatment, $\%$ & 92.00 & 91.00 & 96.000 & 92.00 & 93.00 \\
\hline Saturation, standard treatment, \% & 93.00 & 91.00 & 97.000 & 92.00 & 95.00 \\
\hline Saturation, additional hemoperfusion, $\%$ & $97.00^{*}$ & 95.00 & 98.000 & 96.00 & 98.00 \\
\hline Leukocytes, before treatment, $\times 10^{9} / \mathrm{L}$ & 14.45 & 5.50 & 27.600 & 11.70 & 16.00 \\
\hline Leukocytes, standard treatment, $\times 10^{9} / \mathrm{L}$ & 12.40 & 10.60 & 13.400 & 12.00 & 13.20 \\
\hline Leukocytes, additional hemoperfusion $\times 10^{9} / \mathrm{L}$ & $10.20^{*}$ & 6.10 & 16.000 & 8.80 & 11.60 \\
\hline Band neutrophils, before treatment, $\%$ & 19.00 & 7.00 & 48.000 & 15.00 & 30.00 \\
\hline Band neutrophils, standard treatment, $\%$ & 12.00 & 8.00 & 18.000 & 9.00 & 16.00 \\
\hline Band neutrophils, additional hemoperfusion, $\%$ & $11.00^{*}$ & 7.00 & 16.000 & 9.00 & 14.00 \\
\hline Amylase, before treatment, U/L & 976.50 & 453.00 & 3240.000 & 852.00 & 1982.00 \\
\hline Amylase, standard treatment, U/L & $772.00^{*}$ & 664.00 & 999.000 & 732.00 & 882.00 \\
\hline Amylase, additional hemoperfusion, U/L & $206.00 * * *$ & 68.00 & 452.000 & 112.00 & 301.20 \\
\hline Bilirubin, before treatment, $\mu \mathrm{mol} / \mathrm{L}$ & 46.50 & 12.41 & 439.000 & 29.00 & 65.00 \\
\hline Bilirubin, standard treatment, $\mu \mathrm{mol} / \mathrm{L}$ & 36.00 & 24.00 & 59.000 & 29.00 & 38.90 \\
\hline Bilirubin, additional hemoperfusion, $\mu \mathrm{mol} / \mathrm{L}$ & $21.60 * * *$ & 5.60 & 88.000 & 11.00 & 39.80 \\
\hline Creatinine, before treatment, $\mu \mathrm{mol} / \mathrm{L}$ & 110.00 & 39.00 & 510.000 & 89.00 & 179.00 \\
\hline Creatinine, standard treatment, $\mu \mathrm{mol} / \mathrm{L}$ & $85.00^{*}$ & 43.00 & 264.000 & 62.00 & 127.00 \\
\hline Creatinine, additional hemoperfusion, $\mu \mathrm{mol} / \mathrm{L}$ & $65.00^{* * *}$ & 43.00 & 124.000 & 56.00 & 86.00 \\
\hline Urea, before treatment, $\mathrm{mmol} / \mathrm{L}$ & 18.00 & 2.49 & 46.370 & 12.82 & 22.00 \\
\hline Urea, standard treatment, $\mathrm{mmol} / \mathrm{L}$ & 15.17 & 6.50 & 22.840 & 10.12 & 17.50 \\
\hline Urea, additional hemoperfusion, $\mathrm{mmol} / \mathrm{L}$ & $6.85^{* * *}$ & 2.60 & 31.200 & 4.30 & 10.00 \\
\hline Diastase, before treatment, U/L & 996.50 & 70.46 & 9768.700 & 234.00 & 2543.00 \\
\hline Diastase, standard treatment, U/L & 931.00 & 316.00 & 7863.000 & 516.00 & 1998.00 \\
\hline Diastase, additional hemoperfusion, U/L & $239.00 * * *$ & 51.50 & 989.000 & 186.00 & 517.20 \\
\hline Procalcitonin, before treatment, $\mathrm{ng} / \mathrm{mL}$ & 3.79 & 0.90 & 12.200 & 2.20 & 8.50 \\
\hline Procalcitonin, standard treatment, ng/mL & $3.05^{*}$ & 0.22 & 6.200 & 2.10 & 3.60 \\
\hline Procalcitonin, additional hemoperfusion, ng/mL & $1.40 * * *$ & 0.14 & 6.400 & 0.50 & 3.11 \\
\hline Glasgow Coma Scale, before treatment, points & 13.00 & 13.00 & 14.000 & 13.00 & 13.00 \\
\hline Glasgow Coma Scale, standard treatment, points & 13.00 & 13.00 & 14.000 & 13.00 & 13.00 \\
\hline $\begin{array}{l}\text { Glasgow Coma Scale, additional hemoperfusion, } \\
\text { points }\end{array}$ & $15.00^{*}$ & 14.00 & 15.000 & 15.00 & 15.00 \\
\hline Pulse, before treatment, beats/min & 112.50 & 82.00 & 130.000 & 98.00 & 116.00 \\
\hline Pulse, standard treatment, beats/min & $96.00 *$ & 78.00 & 102.000 & 86.00 & 98.00 \\
\hline Pulse, additional hemoperfusion, beats/min & $84.00 *$ & 72.00 & 98.000 & 82.00 & 94.00 \\
\hline Malonic dialdehyde, before treatment, $\mu \mathrm{mol} / \mathrm{L}$ & 5.60 & 3.80 & 7.200 & 4.80 & 6.20 \\
\hline Malonic dialdehyde, standard treatment, $\mu \mathrm{mol} / \mathrm{L}$ & $3.80 *$ & 2.80 & 4.400 & 3.60 & 4.20 \\
\hline $\begin{array}{l}\text { Malonic dialdehyde, additional hemoperfusion, } \\
\mu \mathrm{mol} / \mathrm{L}\end{array}$ & $1.60 * * *$ & 1.40 & 2.100 & 1.50 & 1.80 \\
\hline
\end{tabular}




\begin{tabular}{|l|c|c|c|c|c|}
\hline Diene conjugates, before treatment, $\mu \mathrm{mol} / \mathrm{L}$ & 4.60 & 4.20 & 5.400 & 4.40 & 5.20 \\
\hline Diene conjugates, standard treatment, $\mu \mathrm{mol} / \mathrm{L}$ & 3.40 & 3.20 & 3.800 & 3.20 & 3.60 \\
\hline $\begin{array}{l}\text { Diene conjugates, additional hemoperfusion, } \\
\mu \mathrm{mol} / \mathrm{L}\end{array}$ & $1.20^{* * *}$ & 1.00 & 1.400 & 1.20 & 1.30 \\
\hline
\end{tabular}

Note*- reliable index changes $(\mathrm{P}<0.005)$ relative to the pre-treatment index;

** - reliable index changes $(\mathrm{P}<0.005)$ relative to the index for the standard therapy group

The hemoperfusion group revealed reliable $(\mathrm{P}<0.005)$ decrease of procalcitonin indices $(2.18$ times $)$, leukocyte number (1.22 time), stab neutrophil number (1.73 time), amylase (4.74 times), diastase (3.9 times), and bilirubin (1.67 time), as compared to the results achieved with the drug therapy.

The increased level of lipid peroxidation markers, i.e. malonic dialdehyde and diene conjugate, was found in the patients. The increase is indicative of the adverse effect of lipid peroxidation in AP pathogenesis. In both groups, indices improved due to the treatment. However, the combined standard therapy and hemoperfusion resulted in reliable normalisation of the markers' level, as compared to the group of undergoing standard therapy. Presumably, hemoperfusion decreases the blood content of toxic products that had formed owing to an increased lipid peroxidation activity.

To our mind, one of the significant positive effects was the decrease of encephalopathy manifestation. In 5 patients, an expressed encephalopathy was observed with 11 points following the Glasgow Coma Scale. Despite the intensive treatment of AP, the positive changes in hemodynamics and laboratory indicators, the encephalopathy manifestation did not decrease. The usage of the $1^{\text {st }}$ séance of hemoperfusion caused an increase in the Glasgow Coma Scale level up to 13 points, after the next hemoperfusion it equalled 15.

The term "hemoperfusion (in the post-Soviet countries - hemosorption) is a treatment method which relies on the transfer of patient's blood through the filter with sorbent - carbon resin or activated carbon $[9,10]$. The filtered blood comes back to the patient's organism. Hemoperfusion is a good method of extracorporeal reduction of exogenous and endogenous toxins. The current adsorbents are the granules with membranous carbon, activated by cellulose or acryl hydrogel or non-ionic resin (XAD-2 and XAD-4). The activated carbon coating prevents the destruction of blood cells, especially thrombocytes and leukocytes. It is considered that this method is even more effective in toxicology than hemodialysis and peritoneal dialysis, especially when the toxic substances are fat-soluble. Besides, hemosorption, as an additional treatment method, can be used in patients with systemic lupus ery thematosus, cold urticaria, psoriasis, food allergy, bronchial asthma and family hyperlipidemia.

In Ukraine, hemoperfusion (or hemosorption) is a widely spread method of efferent patients' treatment. The hemosorbents like carbon sorbents and ionic resins are used as they are produced in Ukraine. Carbon sorbents of SCN type (1K, SCN-2K) significantly decrease the level of toxins of low and average molecular weight and also protein-bound metabolites $[8,9,11]$. They remove toxic substances such as barbiturates, organophosphorus compounds, chlorinated hydrocarbons, myoglobin and do not influence $\mathrm{K}, \mathrm{Na}, \mathrm{Mg}, \mathrm{Ca}$ concentrations. The effectiveness of carbon sorbents is also seen in case of acetaminophen and tricyclic antidepressants overdose, in terms of systemic inflammatory response syndrome (SIRS) as well.

The received data show a successful usage of hemoperfusion in AP treatment. The advantages of hemoperfusion compared to other methods of extracorporeal purification are high effectiveness and low cost. The cost of hemodialysis and ultra- and hemofiltration is comparatively higher.

\section{Conclusions}

The usage of hemoperfusion in patients with acute non-biliary moderately severe pancreatitis in addition to traditional drug therapy leads to a significant normalisation of amylase, diastase, procalcitonine, bilirubin and leukocytes levels compared to patients who were treated following only the standard protocol drug therapy.

\section{References:}

1. Wei AL, Guo Q, Wang MJ, Hu WM, Zhang ZD. Early complications after interventions in patients with acute pancreatitis. World J Gastroenterol. 2016; 22(9): 2828-36. https://doi.org/10.3748/wjg.v22.i9.2828

2. Tenner S, Baillie J, DeWitt J. Management of Acute Pancreatitis. Am J Gastroenterol. 2013; 108: 1400-1415. https://doi.org/10.1038/ajg.2013.218

3. Antonelli M, Cutuli SL, Ronco C. Polymyxin B hemoperfusion in septic shock: just look at the evidence! Intensive Care Med. 2015; 41(9): 1731-2. https://doi.org/10.1007/s00134-015-3931-x 
4. Kulabukhov VV. Use of an endotoxin adsorber in the treatment of severe abdominal sepsis. Acta Anaesthesiol Scand. 2008; 52(7): 1024-5. https://doi.org/10.1111/j.1399-6576.2008.01677.x

5. Mitaka C, Masuda T, Kido K. Polymyxin B hemoperfusion prevents acute kidney injury in sepsis. J Surg Res. 2016; 201(1): 59-68. https://doi.org/10.1016/j.jss.2015.10.020

6. Yakubchevich RE, Predko VA, Spas VV. Extracorporeal blood correction methods and their impact on products of microbial metabolism in patients with sepsis. Anesteziol Reanimatol. 2015 60(5): 67-70.

7. Hong B, Ling Z, Songmin H, Tao Z. Continuous venovenous hemofiltration and hemoperfusion in successful treatment of a patient with crush syndrome and acute pancreatitis. Ren Fail. 2012; 34(3): 383-6. https://doi.org/10.3109/0886022X.2011.647370

8. Savel'ev VV, Vinokurov MM, Gogolev NM. An analysis of effectiveness of application of various methods of artificial detoxication in patients with sterile phase of pancreatic necroses. Vestn Khir Im I I Grek. 2012; 171(3): 35-8.

9. Lebed'kov EV, Makarov DV, Sarmanaev SKh. Combined application of hemodialysis and hemosorption for the treatment of acute cisplatin poisoning. Klin Med (Mosk). 2009; 87(1): 63-5.

10. Yamashita C, Hara Y, Kuriyama N. Clinical Effects of a Longer Duration of Polymyxin B-Immobilized Fiber Column Direct Hemoperfusion Therapy for Severe Sepsis and Septic Shock. Ther Apher Dial. 2015; 19(4): 316-23. https://doi.org/10.1111/1744-9987.12339

11. Khomyak IV, Rotar OV, Rotar VI. Prognostic significance of elements of the multiorgan insufficiency syndrome and estimation of the patients state severity in accordance to integral scales in an acute necroticpancreatitis. Klin Khir. 2015; (9):16-19. 